\title{
Productivity Dispersion across Districts in Punjab
}

\section{Maryiam Haroon*}

\begin{abstract}
Industrial clusters and special economic zones are key areas of focus for industrial policy makers who are aiming to expand the industrial base and increase competitiveness. Thus, the role of development of industrial clusters in the productivity improvement of manufacturing firms merits attention. We use the firmlevel Census of Manufacturing Industries (CMI) and Directory of Industries (DOI) datasets to empirically investigate the relationship between agglomeration and firm level total factor productivity for different sectors in Punjab, Pakistan. Our findings suggest that there is a correlation between localization, urbanization and total factor productivity of firms in the Punjab. However, the relationship varies by sectors, necessarily pointing industrial policy towards sector-specific recommendations.
\end{abstract}

Keywords: Total factor productivity, industrial concentration, economic geography, Pakistan.

JEL classification: D24, L19.

\section{Introduction}

The concentration of industrial activity has long been a widely studied phenomenon. Agglomeration - defined as the presence of a number of distinct economic units within the same geographical locationoccurs widely across economies of all types (see Krugman, 1995; Duranton and Puga, 2004). One of the seminal contributions of the new economic geography is to explicitly model "the self-reinforcing character of spatial concentration" (Fujita, Krugman \& Venables, 1999; Krugman, 1991; Venables, 1996). Enquiries into the reasons for variation in growth levels and economic activity between geographical locations has long ascribed a role to agglomeration externalities. The basic underlying insight is that, without some form of agglomeration externalities, it is difficult to explain the existence of many cities. Since wages and land rents are typically higher in cities, employers would not locate there unless they were deriving some

\footnotetext{
* Assistant Professor, Department of Economics, and Research Fellow, Centre for Research in Economics and Business. Lahore School of Economics, Pakistan.
} 
benefit from their urban location.

Industrial clusters have been a source of growth in both developed and developing economies as location impacts firms' individual productivity directly through agglomeration externalities. This allocation of factors shapes aggregate productivity (Hsieh and Klenow, 2009). Localization externalities, which are defined as the presence of activity from the same industry in a geographic area, raises productivity though externalities coming from input markets, labor markets or knowledge externalities (Marshall, 1920). Similarly, urbanization or inter-industry agglomeration, defined as the presence of activity from other industries in an area, can also be a source of positive externalities as industries borrow ideas and technology. Industrial diversity also generates pecuniary externalities in the form of output and input linkages (Rosenthal et. al; 2001; Combes et al. 2011) and inter-industry agglomeration economies (Jacobs 1984; Glaeser et al. 1992; Cainelli and Iacobucci, 2012).

Within industrial clusters there is a range of diversification, with some that may be specialized in a very small number of industries as are many medium-size American cities (Henderson, 1997), and others that house differentiated industries such as large metropolises including New York and Tokyo. These cities are highly diversified in that they nest many industries that are not related through direct linkages (Chinitz 1961; Fujita and Tabuchi 1997). Industrial districts involving firms with strong technological or informational linkages, or both (e.g., the Silicon Valley or Italian districts engaged in more traditional activities) as well as factory towns (e.g., Toyota City or IBM in Armonk, New York) manifest various types of local specialization. Therefore, it appears that highly varied size and activity arrangements exist at the regional and urban levels. There are many well-known examples in Pakistan such as the surgical goods and sports goods industries in Sialkot, Pakistan (Atkin et al., 2017; Nadvi, 1999; Nadvi, 2003).

This paper aims to identify the role of agglomeration externalities in the productivity improvement of firms. Based upon our findings we aim to rank sectors to maximize the benefits from industrial clustering. Our research provides recommendations for the development of industrial districts and special economic zones for different sectors in Punjab. Our analysis is based on two firm-level data sets, which are the Census of Manufacturing Industries (CMI) and Directory of Industries (DOI) for 2011 and 2006. Our findings also suggest that there is a correlation between 
localization, urbanization and total factor productivity (TFP) of firms in the province. However, the relationship varies across sectors. Thus, our results suggest that polices focusing on development of special economic zones and industrial parks should be sector-specific rather than general in nature.

\section{Data}

We have used the CMI 2005-06 and 2010-11 for Punjab, Pakistan. The CMI is a firm level data set, which includes information on various firm level characteristics including sales, products, employment, raw materials, energy usage, and other information. We make use of this extensive dataset for two time periods and match the firms using their names, addresses, phone numbers and registration numbers to create a panel of manufacturing firms. We were able to match approximately 1300 firms in both years. We make use of this panel to calculate the productivity of each firm using semi-parametric approaches.

In addition to the CMI, we also make use of the DOI dataset for Punjab, Pakistan in two time periods i.e., 2010-11 and 2005-061. The DOI contains information on all firms in the province with basic information on employment, district, industry and year of establishment. We make use of this dataset to calculate our agglomeration measures. In each year the dataset has information on more than 18,000 firms belonging to different industries. This is a rich dataset that lists all firms in Punjab. Since our access to a data set is limited to Punjab, our main focus is on presenting firm level TFP for Punjab, which is one of the largest and most economically active provinces of the country.

Punjab accounts for almost 60 percent of total annual production of goods and services of the country. The province's Gross Provincial Product grew at an average of 5.5 percent, this being higher than the 4 percent growth rate of the entire country. Manufacturing industries in Punjab contribute almost 58 percent to the overall industrial production of Pakistan and accounts for about 60 percent of value added in the country's manufacturing sector. So, the country's economic health is directly related to the province's growth rate.

The overall industrial structure in the province is dominated by small and medium enterprise (SME) clusters in Punjab. The province provides a very interesting case for analyzing industrial clusters primarily

\footnotetext{
${ }^{1}$ For graphs and tables we also use DOI 2014.
} 
because it comprises both specialized and diversified districts. Some of the most concentrated industries are textiles, surgical instruments, auto parts, leather, and sports. Prominent concentrated districts include Lahore, Faisalabad, Sialkot, Gujranwala and Sheikhupura. Out of these districts, some are specialized ones such as Faisalabad which is considered as the main hub of textiles while Lahore is diversified in different industries such as food, auto parts, equipment and furniture.

\section{Empirical Strategy}

We aim to empirically estimate the correlation between TFP and agglomeration. We estimate the following equation:

$$
\alpha_{i y r t}=\gamma l o c_{y r t}+\delta u r b_{r t}+\varphi X_{i y r t}+\varepsilon_{i y r t}
$$

In Equation (1a) total factor productivity $\left(\alpha_{i y r t}\right)$ of firm $i$ in industry $y$ region $r$ and time $t$ is a function of localization $\left(l o c_{y r t}\right)$ of industry $y$ region $r$ and time $t$, urbanization $\left(u r b_{r t}\right)$ in region $r$ and time $t$, firm level controls $\left(X_{i y r t}\right)$ and an error term $\varepsilon_{i y r t}$.

Our dependent variable $\left(\alpha_{\text {iyrt }}\right)$ is the TFP of firms calculated using the semi-parametric approach which includes Olley and Pakes (1996) and Levinsohn and Petrin (2003). We incorporated agglomeration using two components, which are localization $\left(l o c_{y r t}\right)$ and urbanization $\left(u r b_{r t}\right)$. Localization is referred to as the presence of similar activity (or presence of the same industry) in a region whereas urbanization refers to the presence of diversified activity (or presence of multiple industries). Localization in this study is taken as a relative measure which is defined as total employment in a sector $y$ and district $r$ as a ratio of total employment of a sector in Punjab. Urbanization is defined as total employment in a district $r$ as a ratio of total employment in Punjab (irrespective of sector). We used the relative measures as compared to absolute measures since districts are not of equal size. Thus, relative measures are superior to absolute measures since relative measures account for region size. Our estimations will control for ownership status (private enterprise, public enterprises or foreign collaboration) and regions of Punjab (north, south, central or west), physical capital and labor. 


\section{Findings and Analysis}

Our data presents some interesting facts about spatial patterns or layout of firms and sectors in Punjab. Figure 1 plots employment of firms and sectors across districts. Analyzing the spatial distribution of firms and sectors, we find that firms and sectors are mainly concentrated in a few districts and there is unequal distribution of activity, with greater concentrations in the central region of Punjab. Much of the activity is concentrated in the central part of Punjab, with highest levels of activity being located in the Lahore, Gujrat, Sialkot, Gujranwala, Faisalabad and Kasur districts. Following this, a moderate level of industrial activity can be witnessed in the districts of the southern Punjab including Bahawalpur, Rahim Yar Khan and Multan. Whereas west and north Punjab have the least activity present in terms of both firms and sectors. This clearly gives us the picture that firms, employment and sectors are not uniformly distributed across Punjab with central Punjab considered as the main hub of economic activity in Punjab.

\section{Figure 1: Distribution of Firms and Sectors Across Districts of Punjab, Pakistan}

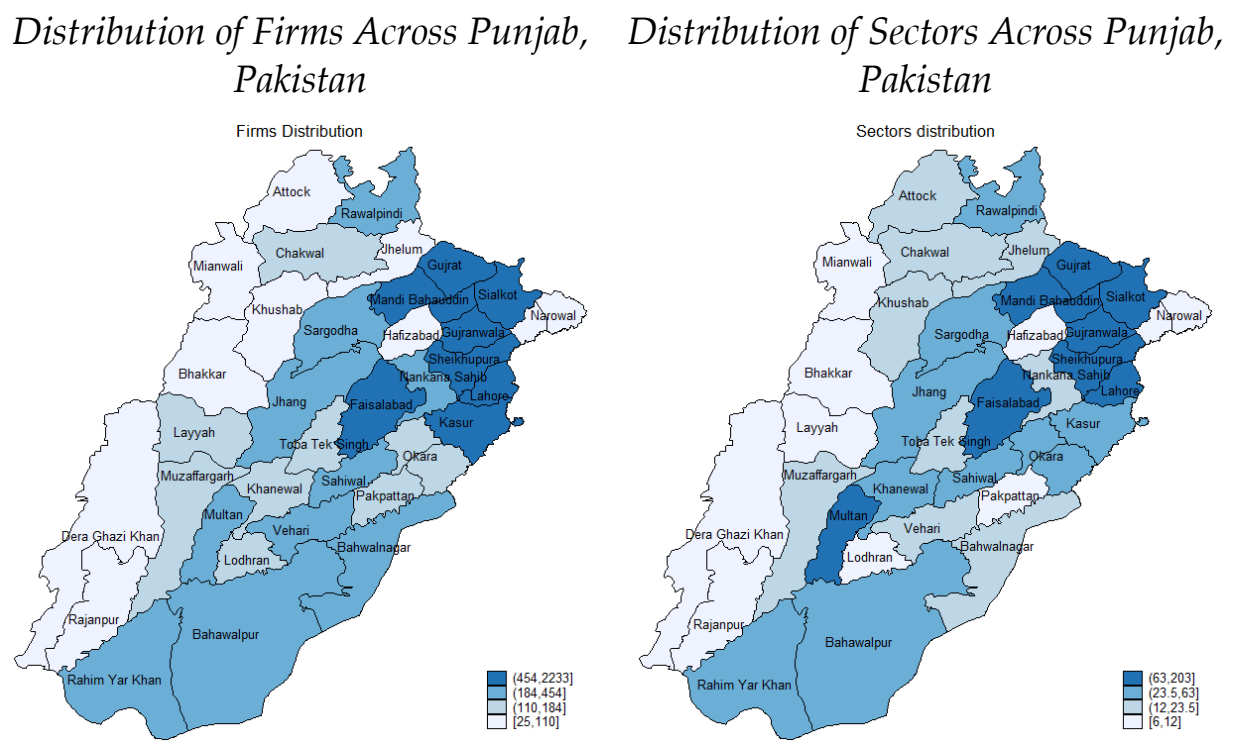

Source: Authors' calculations based on Directory of Industries 2014 for Punjab, Pakistan. Note: Graphs used 5-digit industrial classification to define sectors.

Similarly, when we plot firms from various sectors across districts in Punjab as shown in Figure 2, we find some interesting results. Some 
sectors are highly concentrated while others are dispersed. We find that $90 \%$ of firms in the sports and surgical industries are concentrated in the Sialkot district alone. Forty percent of firms in the textile sector are concentrated in Faisalabad and the rest of the textile firms are dispersed across other districts. We see leather and food sector is mostly dispersed across districts, while the electrical equipment industry is mostly concentrated in Lahore and in Gujranwala. Thus, this raises the question that do firms from sectors which are concentrated in a few districts derive significant productivity benefits?

\section{Figure 2: Distribution of Firms from Major Industries Across District in} Punjab, Pakistan

Distribution of Firms from Sports Industry

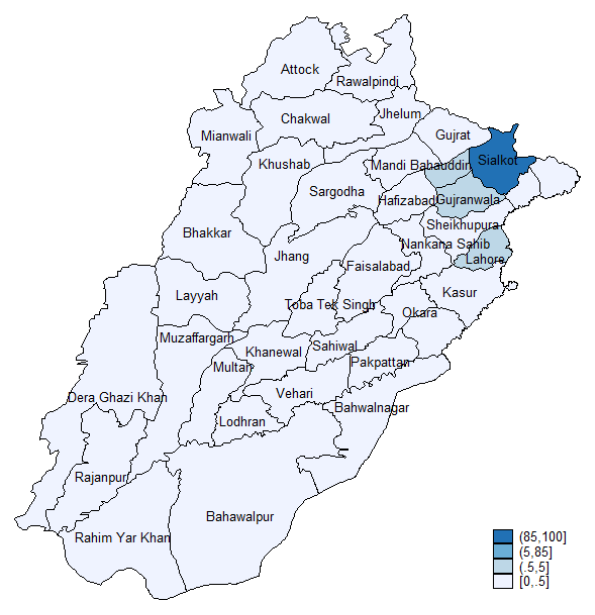

Distribution of Firms from Surgical Industry

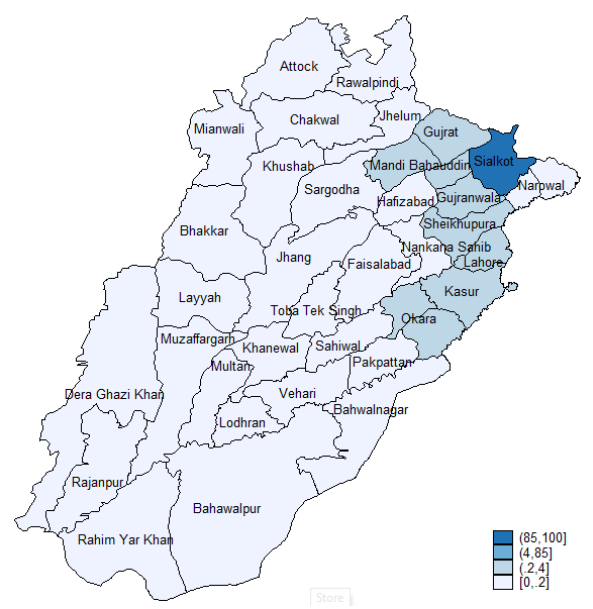


Distribution of Firms from Textile Industry

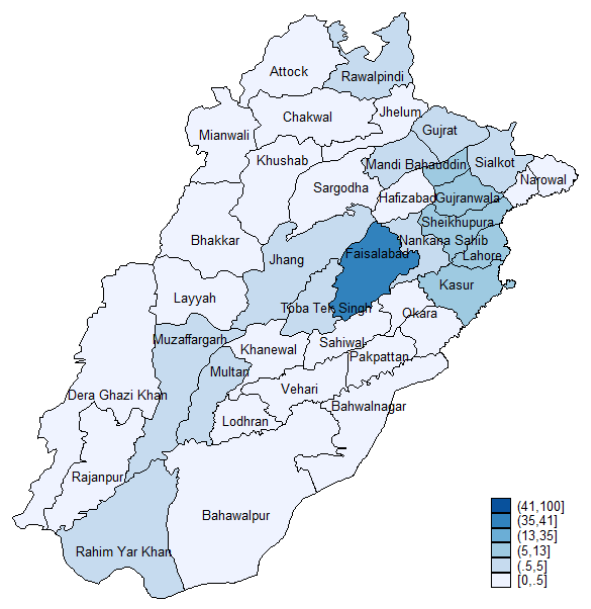

Distribution of Firms from Electrical Equipment Industry

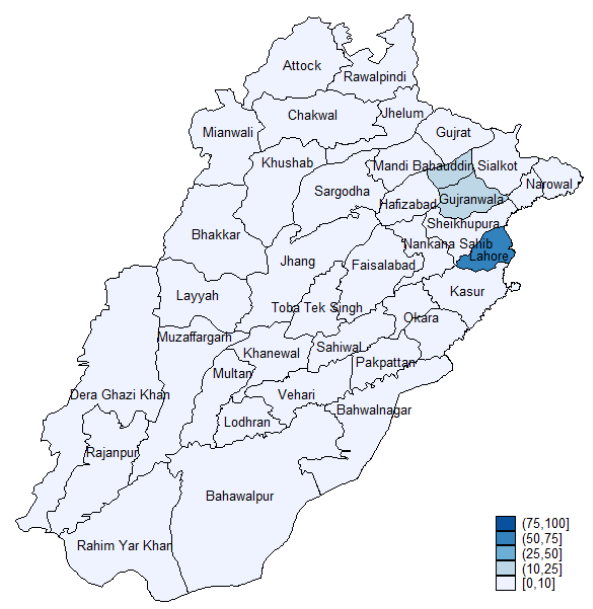

Distribution of Firms from Leather

Industry

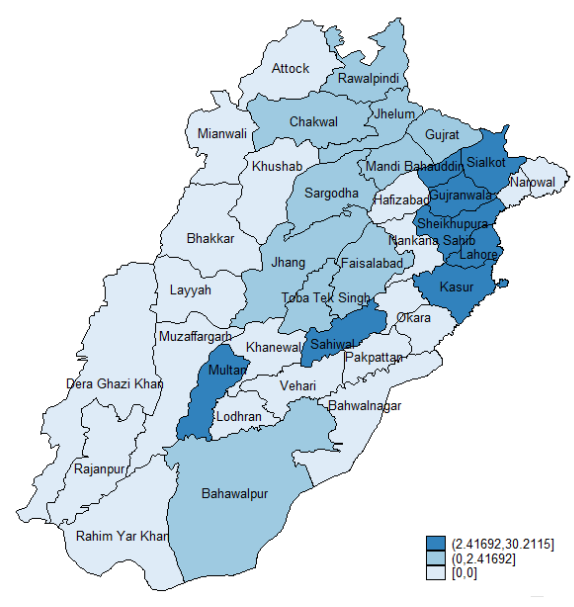

Distribution of Firms from Food Industry

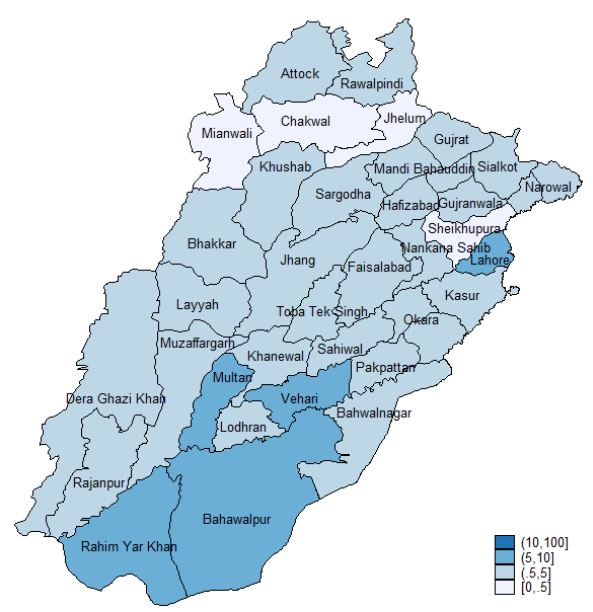

Source: Authors' calculations based on Directory of Industries 2014 for Punjab, Pakistan. Note: Two-digit industrial classification has been used to define Textile, Leather, Food and Electrical equipment industry and four-digit industrial classification has been used for Sports and Surgical instrument industry. The data used in the graphs is presented in Table $2 \mathrm{~A}$ in appendix section.

In Figure 3, the distributions of TFP by region demonstrate that central Punjab has the least dispersed productivity with the highest mode. In comparison, north, south and west Punjab on average have the same (lower) level of average productivity and a more dispersed distribution. We then plot the log of total factor productivity for six individual districts of 
central Punjab (in Figure 4), which contains much of Punjab's industrial activity. We find that Sialkot has higher productivity firms as compared to other districts, which is as expected since Sialkot comprises the sectors which are heavily export-oriented. Sheikhupura and Lahore follow a similar trend with greater-than-average productive firms, while the distribution is more dispersed than Sialkot. Gujrat and Gujranwala have less productive firms. However, the distribution is narrow or less dispersed depicting that a large share of the extant firms are less productive.

\section{Figure 3: Productivity distribution across regions of Punjab}

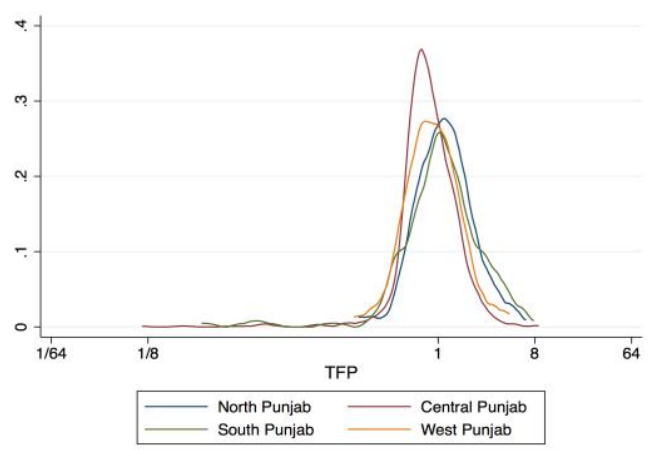

Source: Authors' calculations based on CMI Punjab, 2011 and 2006.

Note: These graphs used TFP derived from regression using Olley and Pakes (1996) estimation method.

\section{Figure 4: Productivity distribution across districts in Central Punjab}

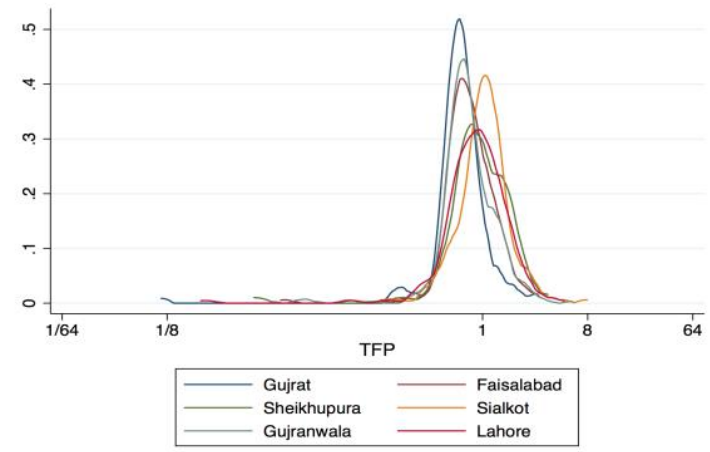

Source: Authors' calculations based on CMI Punjab, 2011 and 2006.

Note: These graphs used TFP derived from regression using Olley and Pakes estimation method.

We then plot the productivity of firms with respect to agglomeration (shown in Figure 5). We divided districts into four categories based upon their level of agglomeration. Categorization of agglomeration was done using the 
employment share in a district as a ratio of total employment in Punjab using the Directory of Industries dataset. The four categories are least agglomerated, somewhat agglomerated, highly agglomerated and very highly agglomerated regions. The graph depicts that very highly agglomerated regions have the least dispersion. It also shows that the least agglomerated regions have the greatest dispersion. As the level of agglomeration declines from very highly agglomeration to least agglomerated, the distribution becomes wider. This motivates us to examine that whether agglomeration and firm productivity are correlated.

\section{Figure 5: Productivity distribution according to level of agglomeration} Punjab

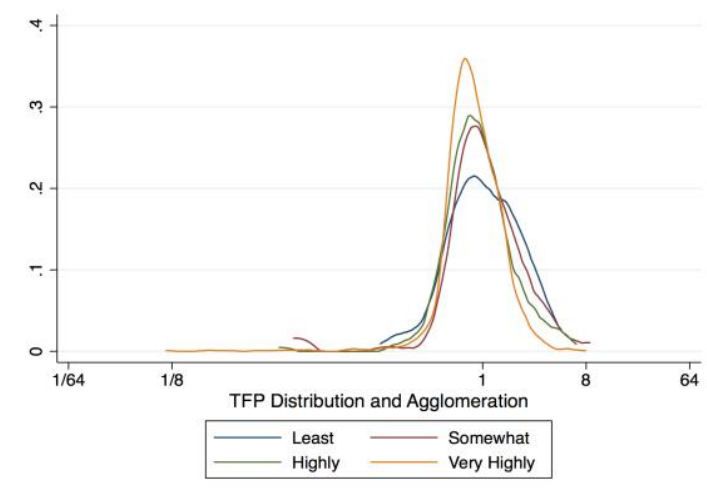

Source: Authors' calculations based on CMI Punjab, 2011 and 2006.

Note: These graphs used TFP derived from regression using Olley and Pakes (1996) estimation method. Agglomeration categorized based upon employment in a district as a share of total employment in Punjab using Directory of Industries (2006).

In order to find whether agglomeration is correlated with the productivity of firms, we estimated two-digit sector-level regressions to find the correlation between agglomeration and TFP. The correlation estimates of agglomeration economies (localization and urbanization) and total factor productivity for different industries at 2-digit industrial classification are presented in Table 1 and graphically represented in Figure 6. Based upon our findings, we identify whether a sector benefits from localization and/or urbanization economies. If an industry is likely to benefit from localization economies, then we may be able to recommend the development of specialized industrial clusters. But if an industry benefits from urbanization economies, then we may be able to recommend the development of special economic zones which are not specialized industrial clusters. After we identify the source of benefit for each industry we present our suggestions in Table 2. In Figure 7, for each industry we 
recommend the location choice for the development of industrial clusters or special economic zones based upon our previous findings.

Table 1 and Figure 6 presents findings from sector-level regressions and reveal that localization and urbanization economies matter in the case of Punjab. However, they are beneficial for some sectors only.

\section{Figure 6: Ranking sectors in terms of benefits from industrial concentration in Punjab}

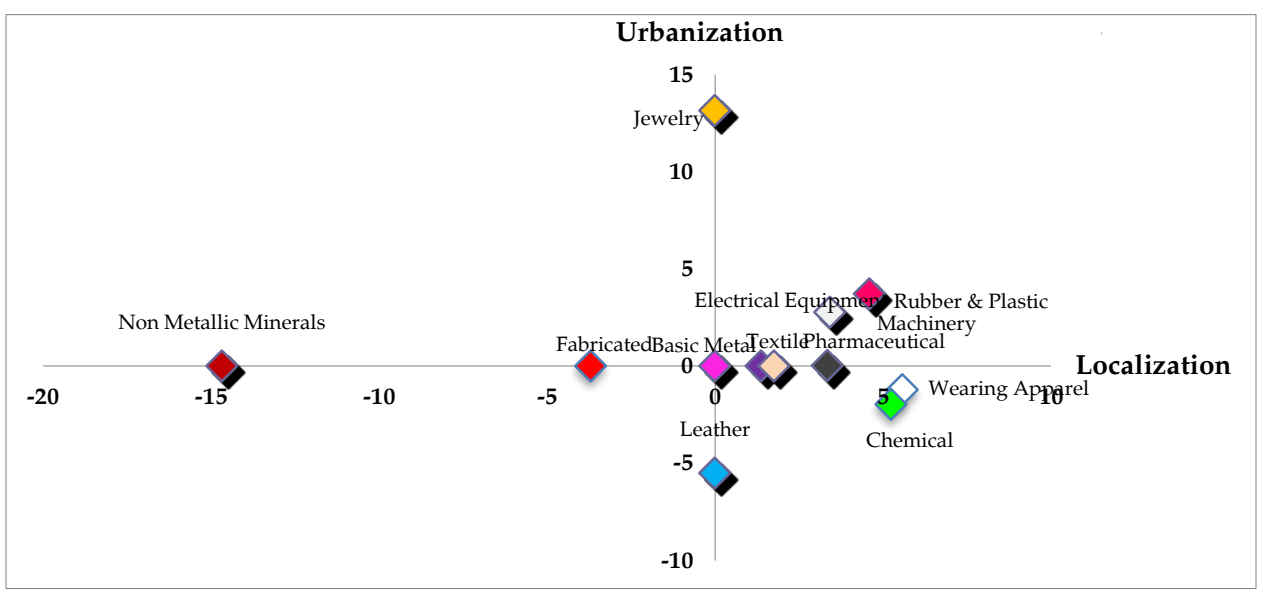

Source: Authors' calculations based on CMI (2011 and 2006) and DOI (2011 and 2006) for Punjab.

Note: Regression estimates from agglomeration and productivity estimation for different sectors, where sectors have been defined using two-digit industrial classification.

Our findings suggest that localization but not urbanization economies are beneficial for the textile and pharmaceuticals sectors (Table 1 , Column 1\&5). The two industries will benefit if there is a specialized policy designed to make it more concentrated. The policy focus for both sectors should be on promoting the development of industrial clusters.

In addition to this, there are sectors where not only localization economies are beneficial but the urbanization economies are beneficial as well. These sectors include rubber and plastic (Table 1, Col 6), electrical equipment (Table 1, Col 10) and machinery equipment (Table 1, Col 11). These sectors not only require spatial proximity to their own industry, but require spatial proximity to other similar or different industries as well which can possibly be their suppliers, buyers or input providers. The policy focus for such sectors could be to promote proximity both to their own industry but bring other industries closer to them as well. 
We also find that spatial proximity to similar activity in an area has a positive relation, while the greater activity from other sectors has a negative relation on average with the total factor productivity of firms for wearing apparel (Table 1, Col 2) and chemical industries (Table 1, Col 4). The two industries are quite different in nature; nonetheless, a similar policy focus can be fruitful for the sectors. However, urbanization is not on average beneficial for these firms' TFP and this might be because these firms do not require specialized inputs and labor. This creates competition for resources and reduces the firm's productivity. The policy should focus on promoting proximity to its own industry and the development of industrial clusters but not to other sectors.

Industrial concentration is not beneficial for some of the sectors which include non-metallic minerals (Table 1, Col 7) and fabricated metals (Table 1, Col 9). These are the sectors for which the policy focus should not be that of creating nor establishing industrial clusters and special economic zones. The presence of similar firms has a negative correlation with the firm's TFP which thus suggests that the presence of similar firms is harmful for firms.

For the leather industry (Table 1, Column 3), localization economies do not matter and urbanization economies are harmful for the firm's productivity. Industrial policy should not focus on creating economic zones nor promoting concentration for such industries. The policy focus of such industries should not be to promote spatial proximity.

When we compare our coefficient of localization across sectors, we find that the industries that benefit the most from localization economies are wearing apparel, chemical, rubber and plastic followed by electrical and machinery equipment, and finally textiles and pharmaceuticals. Similarly, our analysis shows that the urbanization economies are most beneficial for the jewelry sector followed by rubber and plastic, electrical equipment and machinery equipment. 


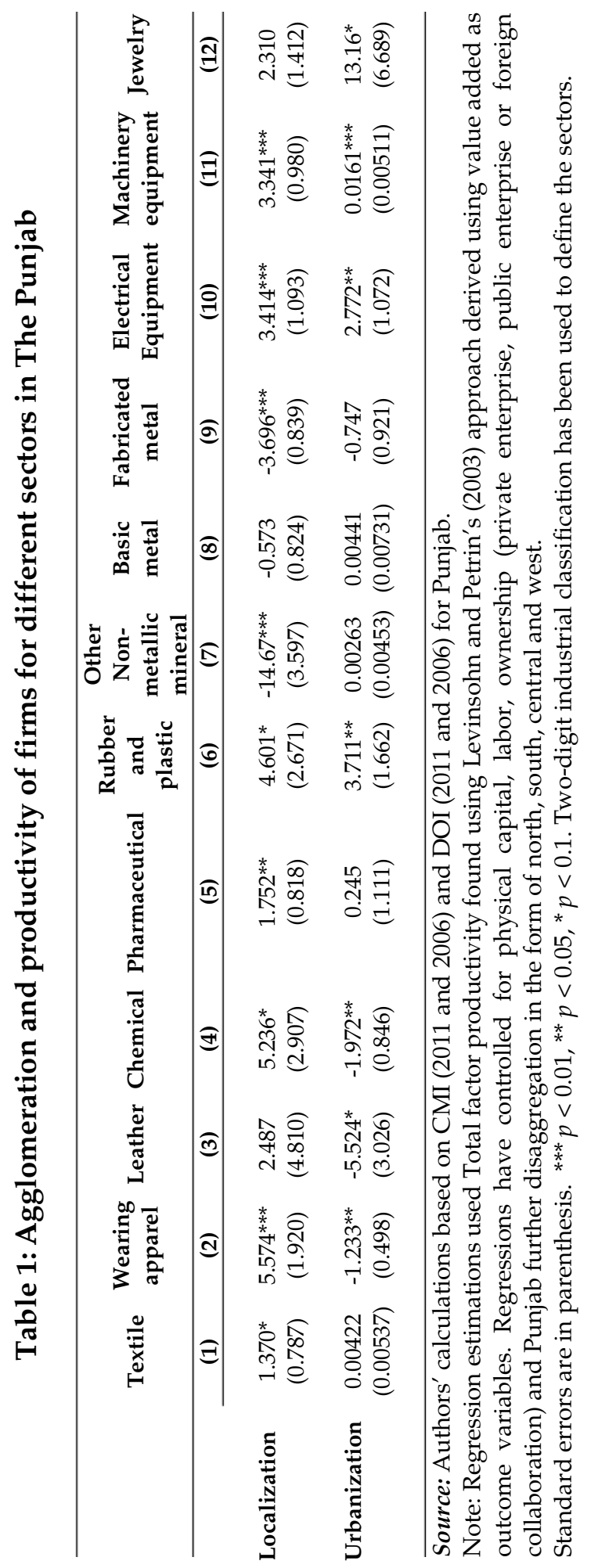


In Table 2, we sort the sectors according to their appropriate policy options. Based upon our regression estimates, we suggest the policy choices for rubber and plastic, electrical equipment and machinery industries should be a combination of industrial clusters and special economic zones. On the other hand, we suggest that for the textile, pharmaceuticals, wearing apparel and chemical industries the policy focus should be the development of industrial clusters. While for the jewelry industry, the policy focus should be the development of special economic zones. Lastly, for industries such as the non-metallic industry, fabricated metal, leather, food, beverage, wood and its products, paper and paper products and motor vehicle industry, we do not recommend promoting greater proximity to other firms, either because it is ineffective or because it would have negative effects on the productivity of the average firm.

Table 2: Ranking Sectors Based Upon Policy Choices

\begin{tabular}{l|l}
\hline $\begin{array}{l}\text { Industrial Cluster and Special } \\
\text { Economic Zones }\end{array}$ & Industrial Cluster only \\
\hline Rubber and plastic Industry & Textile Industry \\
Electrical Equipment Industry & Pharmaceuticals Industry \\
Machinery Equipment & Wearing Apparel Industry \\
& Chemical Industry \\
\hline Special Economic Zones only & None \\
\hline Jewelry Industry & Other Non-Metallic Industry \\
& Fabricated Metal Industry \\
& Leather Industry \\
Basic Metal Industry \\
& Food Industry \\
Beverage Industry \\
Wood and its products Industry \\
Paper and paper product Industry \\
Motor vehicles, trailers, and semi-trailers Industry
\end{tabular}

Note: Based upon the author's results.

Finally, we also compute fitted values of TFP and plot these with our localization variable. The fitted values were calculated from a regression of TFP on all variables included in the previous regression and in addition to a quadratic term. Similar estimations were repeated for urbanization (and its quadratic) as well. This was done to find out whether the policy choices suggested above should focus on making existing clusters stronger (because productivity is rising with localization) or the development of new clusters (if productivity is falling with localization), and find the possible districts for the development of industrial clusters and special economic zones, when those districts are above the trendline 
for the agglomeration-productivity relationship. The results of this are shown in Figure 7.

Figure 7: Identifying location choices for Special Economic Zones and Industrial Clusters

\section{Textile Industry}

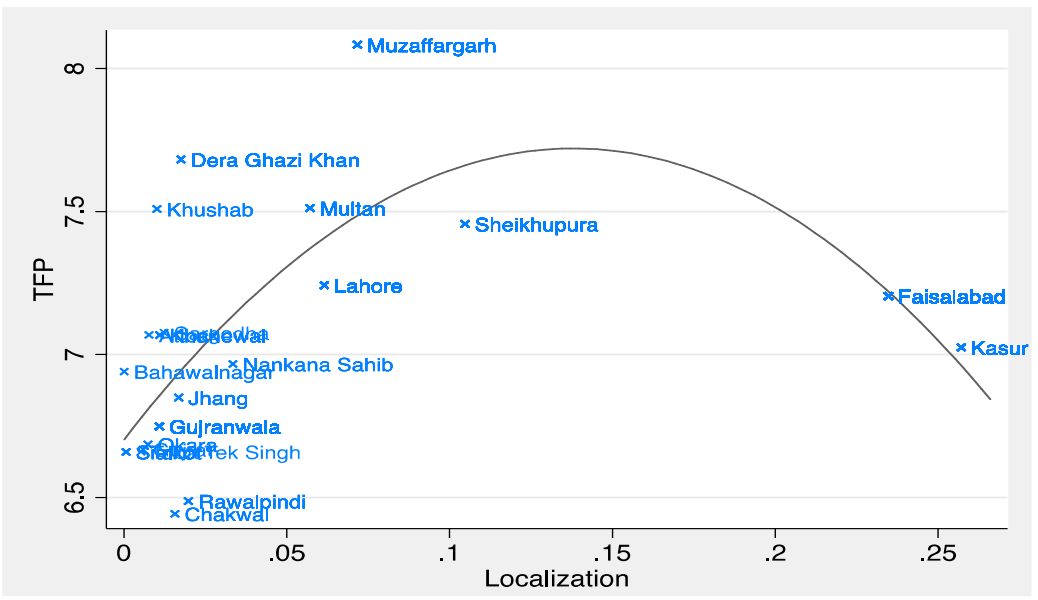

Pharmaceuticals Industry

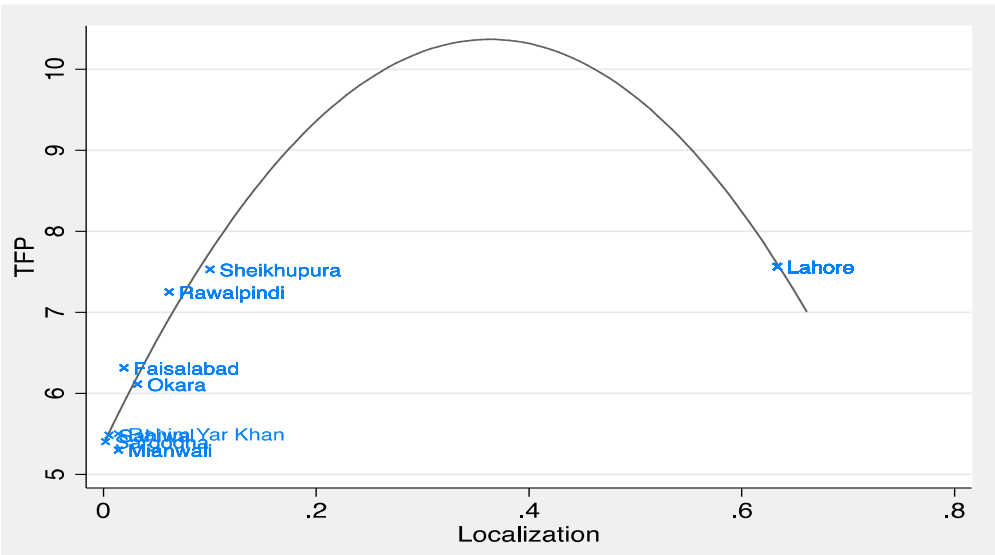




\section{Chemical Industry}

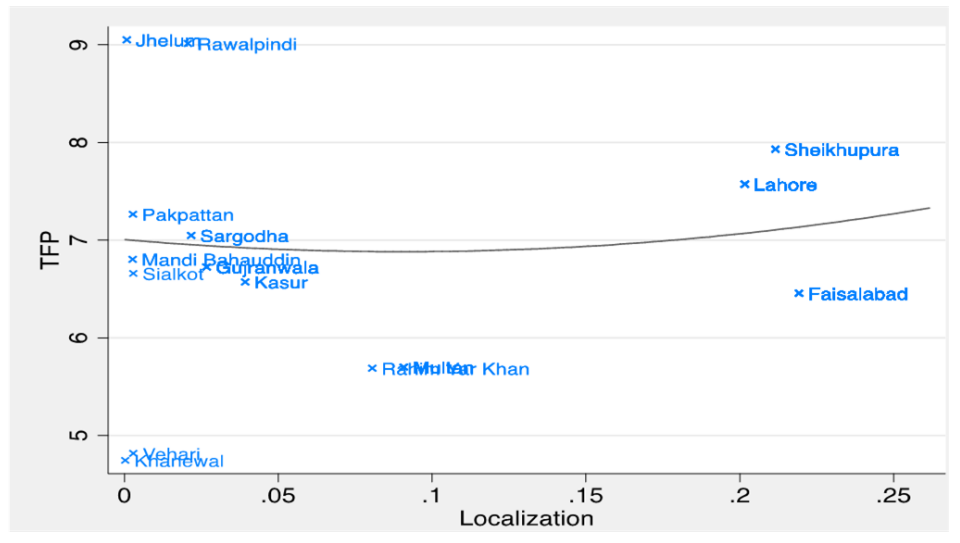

Wearing Apparel Industry

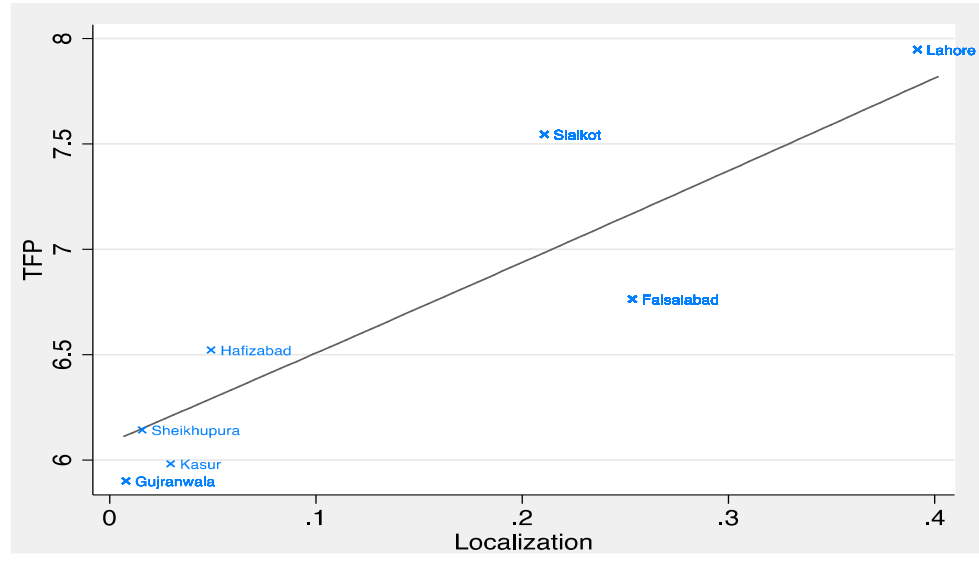

Rubber and Plastic Industry

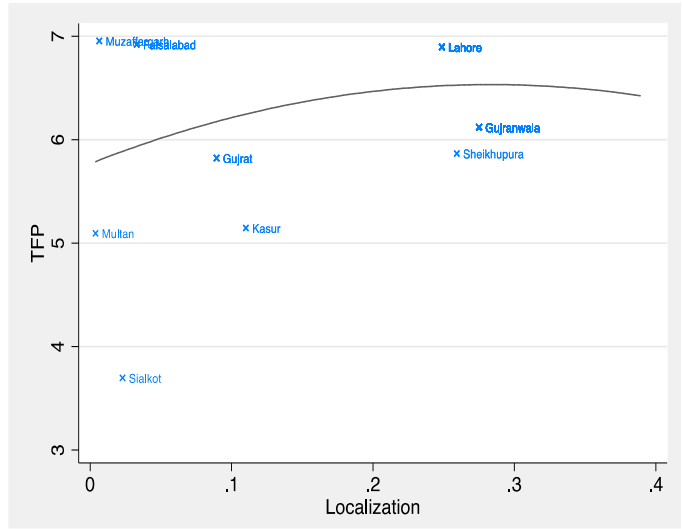



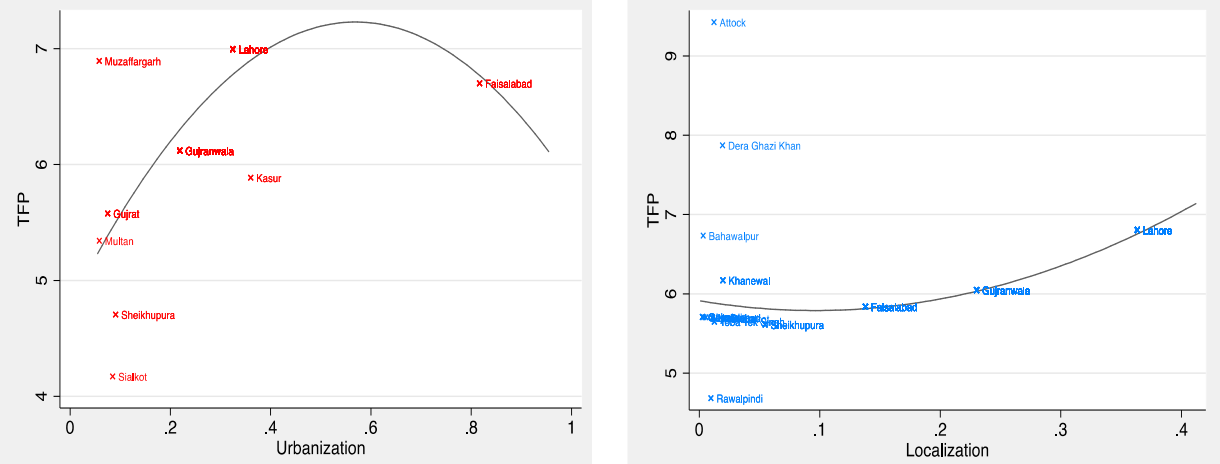

Machinery Equipment Industry

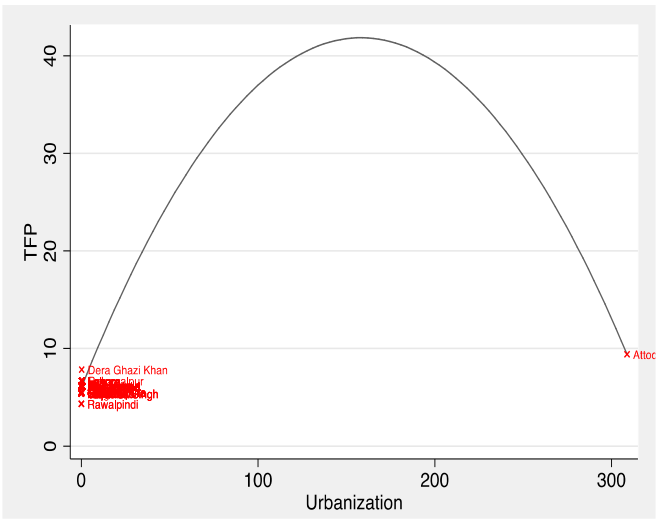

\section{Electrical Equipment Industry}
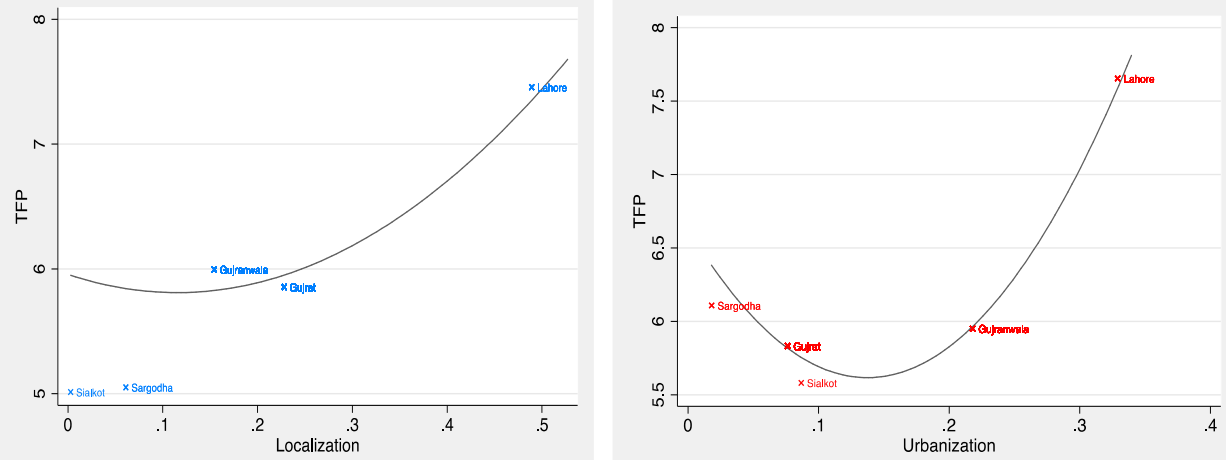

Source: Authors' calculations based on CMI (2011 and 2006) and DOI (2011 and 2006) for Punjab.

Note: Graphs have been created using fitted values of TFP from regressions including a non-linear (quadratic) term. 
Industrial policy should carefully design the development of industrial clusters and special economic zones since, for some sectors, agglomeration in particular districts has reached the point where congestion has occurred and further benefits cannot be extracted from growing existing clusters. In other districts, sector-level productivity is above average or those districts are in the range of an upward sloping agglomerationproductivity relationship. So we provide suggestions for some potential areas where firms could be further agglomerated to benefit from positive location-specific externalities. For instance, for the textile sector, the possible location choices for the development of new industrial clusters could be Multan, Attock, Sargodha, Khushab, Dera Ghazi Khan, Muzaffargarh, Lahore, and Bahawalnagar. In contrast, agglomeration economies in the textile sector have been exhausted in Kasur and Faisalabad. The possible location choices for the development of new industrial clusters for pharmaceuticals could be Rawalpindi, Faisalabad, Sheikhupura, and Okara. For the chemical sectors, possible location choices for industrial clusters include Lahore, Sheikhupura, Jhelum, Rawalpindi, Pakpattan, and Sargodha. Lastly, the wearing apparel industrial clusters could be further developed in Sialkot, Faisalabad, Lahore, or Hafizabad.

For the machinery equipment sector, the development of industrial clusters could be in Faisalabad, Lahore, Gujranwala while the development of special economic zones should be in Dera Ghazi Khan, Rawalpindi, Bahawalpur, or Toba Tek Singh. For the electrical equipment sector, the development of industrial clusters could be in districts such as Lahore, Gujranwala, or Gujrat, while the development of special economic zones should be in Lahore or Gujranwala. The rubber and plastic industry could focus on the development of industrial clusters in districts such as Muzaffargarh, Faisalabad, Gujrat, or Lahore while the industry locations considered for special economic zones should be Gujrat, Multan, Gujranwala, Lahore, Muzaffargarh, or Kasur.

\section{Conclusion}

The literature has gained considerable attention regarding industrial concentration dating back to Marshall (1920). Agglomeration externalities have been used to justify cluster policies by national and local governments in developed and developing countries. In Pakistan, industrial clusters and special economic zones are key areas of focus for industrial policy makers in order to promote the industrial base and increase competitiveness. Thus, the role of the development of industrial clusters in the productivity improvement of manufacturing firms merits attention. 
Using a firm level data set, we empirically investigate the relationship between agglomeration and firm-level productivity for different sectors in Punjab, Pakistan. Our aim is to rank sectors to maximize the benefits from industrial clustering and to highlight the sectors where the development of industrial clusters and special economic zones are considered to be useful. Our analysis is based on two provincial firm level data sets, the Census of Manufacturing Industries (CMI) and the Directory of Industries for 2011 and 2006. In order to find out whether agglomeration is correlated with the productivity of firms we estimated two-digit sector level regressions to find the correlation between agglomeration measured as localization and urbanization and TFP.

Our findings from sectoral level regressions reveal that localization and urbanization economies matter in the case of Pakistan. However, they are beneficial for a limited number of sectors. Localization economies are beneficial for the textile and pharmaceuticals sectors. The sectors that benefit from both localization and urbanization economies include rubber and plastic, electrical equipment and machinery equipment. We also find that spatial proximity to similar activity has a positive effect, while the more intensive activity from outside sectors has a negative relation on the total factor productivity of firms in the wearing apparel and chemical industries. Thus, our results suggest that policies focusing on the development of special economic zones and industrial parks should be sector-specific and not general in nature. 


\section{References}

Alfred, M. (1920). Industry and trade: A study of industrial technique and business organization; their influences on the conditions of various classes and nations, wyd. 3, London, 1920.

Atkin, D., Chaudhry, A., Chaudry, S., Khandelwal, A. K., \& Verhoogen, E. (2017). Organizational barriers to technology adoption: Evidence from soccer-ball producers in Pakistan. The Quarterly Journal of Economics, 132(3), 1101-1164.

Combes, P. P., Duranton, G., \& Gobillon, L. (2010). The identification of agglomeration economies. Journal of Economic Geography, 11(2), 253266.

Cainelli, G., \& Iacobucci, D. (2012). Agglomeration, related variety, and vertical integration. Economic Geography, 88(3), 255-277.

Chinitz, B. (1961). Contrasts in agglomeration: New York and Pittsburgh. The American Economic Review, 279-289.

Duranton, G., \& Puga, D. (2004). Micro-foundations of urban agglomeration economies. In Handbook of Regional and Urban Economics, 4, 2063-2117. Elsevier.

Fujita, M., Krugman, P. R., \& Venables, A. (1999). The spatial economy: Cities, regions, and international trade. MIT press.

Fujita, M., \& Tabuchi, T. (1997). Regional growth in postwar Japan. Regional Science and Urban Economics, 27(6), 643-670.

Glaeser, E. L., Kallal, H. D., Scheinkman, J. A., \& Shleifer, A. (1992). Growth in cities. Journal of Political Economy, 100(6), 1126-1152.

Hsieh, C. T., \& Klenow, P. J. (2009). Misallocation and manufacturing TFP in China and India. The Quarterly Journal of Economics, 124(4), 1403-1448.

Henderson, V. (1997). Externalities and industrial development. Journal of Urban Economics, 42(3), 449-470.

Jacob, J. (1984). Cities and the wealth of nations: Principles of economic life. New York: Vintage. 
Krugman, P., \& Venables, A. J. (1995). Globalization and the Inequality of Nations. The Quarterly Journal of Economics, 110(4), 857-880.

Krugman, P. (1991). Increasing returns and economic geography. Journal of Political Economy, 99(3), 483-499.

Marshall, A. (1920). Industry and trade: A study of industrial technique and business organization; and of their influences on the conditions of various classes and nations. Macmillan.

Nadvi, K. (1999). Collective efficiency and collective failure: The response of the Sialkot surgical instrument cluster to global quality pressures. World Development, 27(9), 1605-1626.

Olley, S.G. and Pakes, A. (1996) The dynamics of productivity in the telecommunications equipment industry. Econometrica, 64, 1263-1298.

Petrin, A., Poi, B. P., \& Levinsohn, J. (2004). Production function estimation in Stata using inputs to control for unobservables. The Stata Journal, 4(2), 113-123.

Porter, M. E. (1996). Competitive advantage, agglomeration economies, and regional policy. International Regional Science Review, 19(1-2), 85-90.

Rosenthal, S. S., \& Strange, W. C. (2001). The determinants of agglomeration. Journal of Urban Economics, 50(2), 191-229.

Venables, A. J. (1996). Equilibrium locations of vertically linked industries. International Economic Review, 341-359. 


\section{Appendix}

Table 1A: Distribution of firms and sectors across districts of Punjab

\begin{tabular}{|c|c|c|}
\hline \multicolumn{3}{|c|}{ Total number of firms and sectors in each district } \\
\hline Districts & Firms & Sectors \\
\hline Attock & 22 & 53 \\
\hline Bahawalnagar & 18 & 214 \\
\hline Bahawalpur & 30 & 357 \\
\hline Bhakkar & 11 & 29 \\
\hline Chakwal & 13 & 139 \\
\hline Dera Ghazi Khan & 12 & 103 \\
\hline Faisalabad & 93 & 1890 \\
\hline Gujranwala & 137 & 1218 \\
\hline Gujrat & 66 & 650 \\
\hline Hafizabad & 12 & 68 \\
\hline Jhang & 41 & 229 \\
\hline Jhelum & 16 & 93 \\
\hline Kasur & 58 & 718 \\
\hline Khanewal & 25 & 175 \\
\hline Khushab & 19 & 110 \\
\hline Lahore & 203 & 2233 \\
\hline Layyah & 7 & 132 \\
\hline Lodhran & 9 & 131 \\
\hline Mianwali & 11 & 77 \\
\hline Multan & 65 & 454 \\
\hline Muzaffargarh & 18 & 133 \\
\hline Nankana Sahib & 18 & 201 \\
\hline Narowal & 8 & 25 \\
\hline Okara & 37 & 127 \\
\hline Pakpattan & 12 & 179 \\
\hline Rahimyar Khan & 26 & 221 \\
\hline Rajan Pur & 6 & 78 \\
\hline Rawalpindi & 63 & 324 \\
\hline Sahiwal & 35 & 225 \\
\hline Sargodha & 40 & 362 \\
\hline Sheikhupura & 88 & 856 \\
\hline Sialkot & 78 & 878 \\
\hline Toba Tek Singh & 18 & 137 \\
\hline Vehari & 13 & 189 \\
\hline
\end{tabular}

Source: Author's calculations based on Directory of Industries 2014 for Punjab, Pakistan. Note: Graphs used 5-digit industrial classification to define sectors. 
Table 2A: Distribution of firms from different sectors across districts of Punjab

\begin{tabular}{|c|c|c|c|c|c|c|c|}
\hline \multicolumn{8}{|c|}{ Percentage of firms in each district } \\
\hline Districts & Sports & Surgical & Textile & Leather & Food & $\begin{array}{c}\text { Electrical } \\
\text { Equipment }\end{array}$ & Chemical \\
\hline Attock & 0.00 & 0.00 & 0.28 & 0.00 & 0.76 & 0.21 & 0.37 \\
\hline Bahawalnagar & 0.00 & 0.00 & 0.14 & 0.00 & 4.23 & 0.00 & 0.19 \\
\hline Bahawalpur & 0.00 & 0.00 & 0.35 & 0.30 & 7.04 & 0.00 & 0.37 \\
\hline Bhakkar & 0.00 & 0.00 & 0.07 & 0.00 & 0.79 & 0.00 & 0.00 \\
\hline Chakwal & 0.00 & 0.00 & 0.32 & 0.30 & 0.18 & 0.00 & 0.19 \\
\hline Dera Ghazi Khan & 0.00 & 0.00 & 0.28 & 0.00 & 2.13 & 0.00 & 0.19 \\
\hline Faisalabad & 0.00 & 0.00 & 40.85 & 0.60 & 4.52 & 0.00 & 12.27 \\
\hline Gujranwala & 1.07 & 1.48 & 8.98 & 3.63 & 4.55 & 18.43 & 4.46 \\
\hline Gujrat & 0.00 & 0.37 & 0.60 & 2.42 & 1.73 & 1.45 & 0.93 \\
\hline Hafizabad & 0.00 & 0.00 & 0.11 & 0.00 & 0.51 & 0.00 & 0.00 \\
\hline Jhang & 0.00 & 0.00 & 1.17 & 0.30 & 2.78 & 0.41 & 0.93 \\
\hline Jhelum & 0.00 & 0.00 & 0.04 & 0.30 & 0.40 & 0.00 & 0.56 \\
\hline Kasur & 0.00 & 1.85 & 8.90 & 30.21 & 3.58 & 0.62 & 2.42 \\
\hline Khanewal & 0.00 & 0.00 & 0.49 & 0.00 & 4.15 & 0.00 & 0.19 \\
\hline Khushab & 0.00 & 0.00 & 0.39 & 0.00 & 0.94 & 0.00 & 0.19 \\
\hline Lahore & 0.53 & 3.32 & 12.26 & 23.56 & 6.65 & 54.66 & 39.22 \\
\hline Layyah & 0.00 & 0.00 & 0.00 & 0.00 & 1.08 & 0.00 & 0.00 \\
\hline Lodhran & 0.00 & 0.00 & 0.07 & 0.00 & 3.25 & 0.00 & 0.00 \\
\hline Mianwali & 0.00 & 0.00 & 0.00 & 0.00 & 0.47 & 0.00 & 2.04 \\
\hline Multan & 0.00 & 0.00 & 2.30 & 2.72 & 6.25 & 0.62 & 3.90 \\
\hline Muzaffargarh & 0.00 & 0.00 & 0.64 & 0.00 & 2.82 & 0.00 & 0.37 \\
\hline Nankana Sahib & 0.00 & 0.00 & 1.59 & 0.00 & 1.48 & 0.00 & 0.19 \\
\hline Narowal & 0.00 & 0.00 & 0.00 & 0.00 & 0.72 & 0.21 & 0.00 \\
\hline Okara & 0.00 & 0.37 & 0.35 & 0.00 & 2.85 & 0.00 & 0.00 \\
\hline Pakpattan & 0.00 & 0.00 & 0.04 & 0.00 & 1.59 & 0.62 & 0.19 \\
\hline Rahimyar Khan & 0.00 & 0.00 & 0.67 & 0.00 & 5.64 & 0.21 & 0.93 \\
\hline Rajan Pur & 0.00 & 0.00 & 0.00 & 0.00 & 1.55 & 0.00 & 0.00 \\
\hline Rawalpindi & 0.00 & 0.00 & 0.53 & 1.81 & 2.46 & 0.62 & 5.76 \\
\hline Sahiwal & 0.00 & 0.00 & 0.35 & 3.02 & 4.12 & 0.00 & 0.56 \\
\hline Sargodha & 0.00 & 0.00 & 0.32 & 1.21 & 2.35 & 0.00 & 1.86 \\
\hline Sheikhupura & 0.00 & 0.37 & 5.34 & 11.18 & 0.29 & 0.00 & 14.50 \\
\hline Sialkot & 97.33 & 90.04 & 0.74 & 11.18 & 0.76 & 1.86 & 1.49 \\
\hline Toba Tek Singh & 0.00 & 0.00 & 1.80 & 1.21 & 2.35 & 0.00 & 0.19 \\
\hline Vehari & 0.00 & 0.00 & 0.11 & 0.00 & 5.17 & 0.00 & 0.19 \\
\hline
\end{tabular}

Source: Author's calculations based on Directory of Industries 2014 for Punjab, Pakistan.

Note: Two-digit industrial classification has been used for Textile, Leather, Food and Electrical equipment industry and four-digit industrial classification has been used for Sports and Surgical instrument industry. 
Table 3A: Average Productivity across districts of Punjab

\begin{tabular}{lc}
\hline District & Average productivity \\
\hline Attock & 8.172 \\
Bahawalnagar & 8.451 \\
Bahawalpur & 7.864 \\
Bhakkar & 8.002 \\
Chakwal & 8.690 \\
Chiniot & 8.817 \\
Dera Ghazi Khan & 8.349 \\
Faisalabad & 7.032 \\
Gujranwala & 6.392 \\
Gujrat & 5.959 \\
Hafizabad & 7.244 \\
Jhang & 7.240 \\
Jhelum & 7.483 \\
Kasur & 7.247 \\
Khanewal & 6.925 \\
Khushab & 8.771 \\
Lahore & 7.321 \\
Layyah & 7.330 \\
Lodhran & 8.018 \\
Mandi Bahauddin & 6.756 \\
Mianwali & 7.084 \\
Multan & 7.215 \\
Muzaffargarh & 8.012 \\
Nankana Sahib & 6.307 \\
Narowal & 5.792 \\
Okara & 6.802 \\
Pakpattan & 7.541 \\
Rahim Yar Khan & 7.653 \\
Rajanpur & 7.251 \\
Rawalpindi & 7.952 \\
Sargodha & 5.487 \\
Sheikhupura & 6.185 \\
Sialkot & 7.608 \\
Toba Tek Singh & 7.367 \\
Vehari & 6.939 \\
Sahiwal & 7.912 \\
\hline
\end{tabular}

Source: Author's calculations based on Census of Manufacturing Industries 2011 for Punjab, Pakistan. 


\section{Table 4A: Average Productivity across industries in Punjab}

\begin{tabular}{lc}
\hline Industries & Average productivity \\
\hline Manufacture of food products & 7.339 \\
Manufacture of beverages & 9.044 \\
Manufacture of textiles & 7.284 \\
Manufacture of wearing apparel & 7.191 \\
Manufacture of leather and related products & 6.622 \\
Manufacture of wood and of products of wood and cork, except & 6.405 \\
furniture; manufacture of articles of straw and plaiting materials & \\
Manufacture of paper and paper products & 6.677 \\
Manufacture of coke and refined petroleum products & 7.788 \\
Manufacture of chemicals and chemical products & 7.241 \\
Manufacture of basic pharmaceutical products and pharmaceutical & 7.549 \\
preparations & \\
Manufacture of rubber and plastics products & 6.874 \\
Manufacture of other non-metallic mineral products & 6.612 \\
Manufacture of basic metals & 7.170 \\
Manufacture of fabricated metal products, except machinery and & 6.360 \\
equipment & \\
Manufacture of computer, electronic and optical products & 7.320 \\
Manufacture of electrical equipment & 6.122 \\
Manufacture of machinery and equipment n.e.c. & 6.545 \\
Manufacture of motor vehicles, trailers and semi-trailers & 7.394 \\
Manufacture of other transport equipment & 6.363 \\
Manufacture of furniture & 5.803 \\
Other manufacturing & 7.895 \\
\hline
\end{tabular}

Source: Author's calculations based on Census of Manufacturing Industries 2011 for Punjab, Pakistan. Note: Two-digit industrial classification has been used to define sectors.

\section{Definitions of important terms}

Localization economies- the benefits firms accrue due to spatial proximity to the same sector of a firm. These benefits are generally categorized as knowledge spill overs, labor pooling and input sharing.

Urbanization economies- the benefits firms accrue due to spatial proximity to the diversified and more sectors. These benefits generally come due to greater and diversified presence of inputs, possibility to vertical and horizontal cooperation, more specialized suppliers.

Special economic zones- A special economic zone is an area in which the business and trade laws are different from the rest of the country. SEZs are located within a country's national borders. These zones are not specialized for one particular industry.

Industrial clusters- Industry clusters are groups of similar and related firms in a defined geographic area that share common markets, technologies, worker skill needs, and which are often linked by buyer-seller relationships. 